\title{
PENGARUH MEDIA PEMBELAJARAN GEOBOARD TERHADAP HASIL BELAJAR SISWA
}

\section{EFFECT OF GEOBOARD LEARNING MEDIA TO STUDENT LEARNING RESULTS}

\author{
Lastrijanah $^{1 \mathrm{a}}$, T Prasetyo ${ }^{1}$, dan A Mawardini1 \\ 1 Program Studi Pendidikan Guru Sekolah Dasar, Fakultas Keguruan dan Ilmu Pendidikan, \\ Universitas Djuanda Bogor, Jl. Tol Ciawi No. 1 Kotak Pos 35 Ciawi Bogor 16720 \\ a Korespondensi: Lastrijanah, Email: janahlastri@gmail.com \\ (Diterima: 17-07-2017; Ditelaah: 18-07-2017; Disetujui: 01-09-2017)
}

\begin{abstract}
The purpose of this study is to examine the influence of learning media geoboard on student learning outcomes. The research was conducted at SDN Sindangkarsa 2 Kecamatan Tapos Kota Depok, with sample of 39 students. The research technique used is quantitative with the design experiment method, nonequivalent control group design pretest posttest. The data were collected using observation, questionnaire, and interview techniques. The results of the research analysis yielded $\mathrm{T}_{\text {table }}>\mathrm{T}_{\text {hitung }}$ for 2,111>1,687 which means Geoboard media in learning showed a positive influence on student learning result of mathematics.
\end{abstract}

Keywords: geoboard learning media, learning outcomes, mathematics.

\begin{abstract}
ABSTRAK
Tujuan penelitian ini adalah untuk menguji pengaruh media pembelajaran geoboard terhadap hasil belajar siswa. Penelitian dilaksanakan di SDN Sindangkarsa 2 Kecamatan Tapos Kota Depok, dengan sampel penelitian sebanyak 39 siswa. Teknik penelitian yang dipakai adalah kuantitatif dengan metode eksperimen desain nonequivalent control group design pretest posttest. Data penelitian dikumpulkan menggunakan teknik observasi, angket, dan wawancara. Hasil analisis penelitian menghasilkan nilai $\mathrm{T}_{\text {tabel }}>\mathrm{T}_{\text {hitung }}$ sebesar $2.111>$ 1.687 yang berarti media Geoboard dalam pembelajaran menunjukkan adanya pengaruh positif pada hasil belajar matematika siswa.
\end{abstract}

Kata kunci: hasil belajar, matematika, media pembelajaran geoboard.

Lastrijanah, T Prasetyo, dan A Mawardini. 2017. Pengaruh media pembelajaran geoboard terhadap hasil belajar siswa. Didaktika Tauhidi Jurnal Pendidikan Guru Sekolah Dasar 4(2): 87-100.

\section{PENDAHULUAN}

Kajian bidang matematika sangat mendukung perkembangan ilmu pengetahuan. Namun banyak siswa memandang bahwa matematika tergolong mata pelajaran dengan kesulitan tinggi, tidak menyenangkan, dan sering dihindari oleh siswa. Ini berarti bahwa siswa membutuhkan inovasi dalam pelajaran matematika untuk mengatasi kesulitan dalam menyerap materi dan mengerjakan soal (Sundayana 2016). Prestasi belajar siswa sangat berkaitan erat dengan besar atau kecilnya kesulitan siswa memahami materi pelajaran. Hal ini menunjukkan adanya faktor belajar yang belum efektif sehingga motivasi siswa dalam mengikuti 
pembelajaran tergolong rendah. Akibatnya, siswa kurang mampu memahami dan menjawab soal yang dirasa sangat sukar untuk diselesaikan.

Guru harus lebih kreatif dalam menciptakan sebuah pembelajaran inovatif yang memberikan kesan mendalam bagi siswa agar tercapainya tujuan pembelajaran. Dalam sebuah pembelajaran inovatif, guru seharusnya memanfaatkan media pembelajaran untuk mencapai pembelajaran yang efektif. Namun, dalam pengimplementasiannya di lapangan, beberapa guru masih tidak menggunakannya dengan beberapa alasan yaitu persiapannya yang merepotkan, waktu yang terbatas, biaya yang mahal dan sebagainya. Hal tersebut sebenarnya mudah diatasi apabila pengetahuan akan media diketahui, karena banyak ragam media yang dapat dimanfaatkan sesuai dengan waktu, keuangan, maupun bahan yang akan ditelaah. Media pembelajaran disiapkan guru agar bisa memenuhi kebutuhan proses pembelajaran dan untuk mengetahui mengukur sejauh mana kemampuan siswa. Sundayana menyatakan bahwa penggunaan media yang menghubungkan antara simbol dan konsep matematika yang tadinya abstrak berubah menjadi konkret, sehingga pengetahuan tentang konsep dan simbol matematika dapat diketahui sejak dini, sesuai dengan susunan berfikir anak.

\section{MATERI DAN METODE}

\section{Materi}

Kata media diambil dari bahasa Latin yang berarti "perantara". Kata media mengambil wujud tunggal yaitu kata "medium". Dalam bahasa Arab, media mempunyai makna yang sama yakni sebagai perantara ( وسائل) antara pengirim dan penerima pesan, atau dapat juga ditafsirkan sebagai pengantar pesan. Media memiliki berbagai fungsi dan bentuk yang beragam yang berguna untuk mengantarkan pesan yang tersirat saat menyampaikan pembelajaran (Sundayana 2016). Media dalam belajar berfungsi sebagai benda pendamping dimana berfungsi untuk menerjemahkan teori yang abstrak sehingga mudah untuk dipahami. Menurut Heinich et al. (2002), terdapat enam jenis dasar dari media pembelajaran yakni: 1) teks, merupakan komponen dalam suatu media untuk memberikan daya tarik berupa kata-kata dalam menyampaikan informasi; 2) media audio, yang terkesan mendalam terhadap suatu persembahan informasi yang disajikan; 3) media visual, membantu memberikan rangsangan-rangan visual; 4) media gambar gerak, dapat berupa film bergerak ataupun video seperti dalam tayangan televisi; 5) benda-benda tiruan/miniature, benda berdimensi tiga yang menyerupai wujud aslinya dan dapat disentuh; 6) manusia, media yang bermanfaat dalam merubah sikap seseorang.

Geoboard adalah alat bantu dalam mengajarkan konsep geometri, seperti konsep bangun datar, konsep keliling bangun datar, dan menghitung serta menentukan luas sebuah bangun datar (Sundayana 2016). Sundayana juga menguraikan teknik pembuatan media geoboard. Geoboard dibuat dengan menggunakan peralatan berupa pensil, penggaris, gergaji, palu, ampelas dan kuas. Sedangkan bahan-bahan yang bisa digunakan adalah tripleks/papan, paku, lem kayu, cat/pilok, dan karet gelang. Cara pembuatannya, potong dua buah tripleks berukuran sama, tempelkan kedua tripleks tersebut dengan menggunakan lem kayu, sesudah kering lalu ampelas pinggiran triplek tersebut supaya halus, sesudah 
diampelas lalu warnai dengan menggunakan pilok. Setelah cat pilok kering, buatlah persegi kecil berukuran serupa dengan menggunakan mistar dan spidol, kemudian tancapkan paku-paku yang telah disediakan tepat di setiap pertemuan garis.

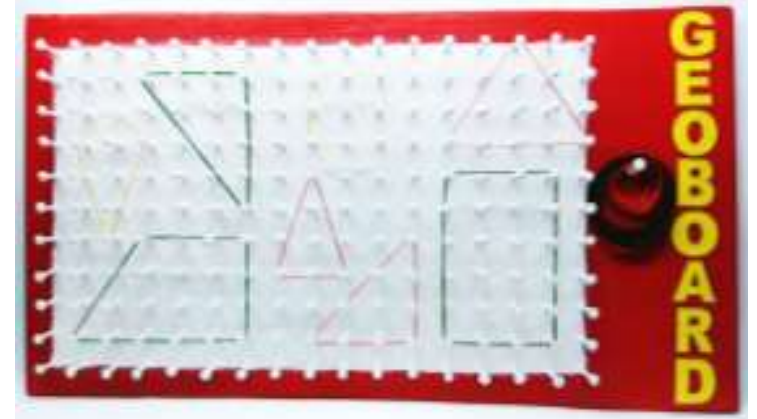

Gambar 1 Media geoboard

Media geoboard memiliki banyak keunggulan di antaranya mudah pembuatannya, lebih ekonomis dengan biaya pembuatan yang murah, dan bisa digunakan berkali-kali, alat dan bahan untuk memproduksinya mudah diperoleh, dan bisa digunakan sebagai media bermain dengan memanfaatkan karet gelang. Adapun kekurangan dari media geoboard, diantaranya lebih banyak menuntut peran guru, media geoboard sangat berbahaya bagi anak karena terdapat paku yang tajam, banyak waktu yang tebuang untuk pembuatannya, dan perlu kesediaan untuk berkorban secara materiil (Santoso 2014).

Hasil belajar dibentuk dari gabungan kata "hasil" dan "belajar". Hasil (product) menurut Purwanto (2014) berarti perolehan yang berasal dari perubahan input akibat aktivitas tertentu secara fungsional. Sementara itu, menurut Usman (2011), belajar menghasilkan peralihan tingkah laku akibat adanya hubungan saling memengaruhi antara individu dengan individu dan lingkungan. Belajar menunjukkan suatu gejala dari usaha seseorang atau disadari, sehingga menghasilkan suatu pengalaman baru ketika dilakukan secara sengaja seseorang memgerjakan proses belajar sebagai hasilnya adalah peralihan tingkah laku yang dengan sadar telah ditetapkan seseorang tersebut.

Matematika merupakan kajian eksak yang terorganisasi. Ilmu ini bersifat deduktif yang membahas pengukuran dan letak, tentang bilangan-bilangan dan hubungannya, ide-ide, struktur-struktur dan hubungannya yang diatur menurut urutan logis, tentang struktur logika, tentang bentuk yang terorganisasi atas susunan besaran yang tak terdefinisi hingga yang terdefinisi, dari aksioma ke dalil atau postulat ke teorema. Ilmu ini dibagi dalam tiga bidang yakni aljabar, analisis, dan geometri (Hamzah dan Muhlisrarini 2014). Hamzah dan Muhlisrarini juga menyebutkan fungsi matematika, yaitu sebagai kumpulan sistem terstruktur bersifat deduktif yang juga biasa disebut ratu dan atau pelayan ilmu. Dalam matematika terdapat pembahasan tentang bangun datar yang berarti bangun yang memiliki dimensi dua berupa panjang dan lebar dan memiliki batasan berupa garis lurus atau garis lengkung (Mulyaningsih 2014). Pembelajaran tentang bangun datar kelas 2 $\mathrm{SD}$, mencakup tentang proses mengenali bangun datar beserta unsur-unsurnya yaitu sisi, dan sudut.

Sisi adalah penggal garis yang membentuk bangun datar, sudut adalah bagian pojok bangun datar, sedangkan titik sudut adalah titik yang berada pada pangkal sudut (Indriyastuti 2012). Berdasarkan banyak garis sisinya bangun datar dikelompokkan menjadi segitiga, segiempat, dan lingkaran. Segitiga memilik tiga sudut dan sisi. Dilihat dari panjang sisinya, segitiga dikelompokkan menjadi tiga yaitu segitiga sama sisi, segitiga sama kaki, dan segitiga sembarang. Sedangkan berdasarkan besar sudutnya, dibagi tiga jenis, yaitu tumpul, 
siku-siku, dan lancip. Segiempat juga termasuk ke dalam bangun datar, pada bangun ini terdapat empat sisi dan empat sudut. Bangun segiempat dapat berupa persegi panjang, persegi, trapesium, layanglayang, jajargenjang, dan belah ketupat. Lingkaran juga termasuk bangun datar satu sisi namun tak bersudut (sehingga jumlah total sudut belok pada lingkaran adalah $0^{0}$ ). Sifat bangun lingkaran yaitu memiliki jarijari, memiliki diameter, panjangnya diameter dua kali panjangnya jari-jari, jarak dari tepi lingkaran ke pusat lingkaran semua sama namun tidak bersudut.

\section{Metode}

\section{Jenis Penelitian}

Metode penelitian dilaksanakan dengan metode kuantitatif, dengan desain nonequivalent control group design pretest posttest. Rancangan penelitian dirinci pada Tabel 1 (modifikasi Sugiyono 2016).

Tabel 1 Desain penelitian

\begin{tabular}{cccc}
\hline & Pretest & Treatment & Posttest \\
\hline Eksperimen & $\mathrm{O}_{1}$ & $\mathrm{X}_{\mathrm{B}}$ & $\mathrm{O}_{2}$ \\
Kontrol & $\mathrm{O}_{3}$ & $\mathrm{X}_{\mathrm{A}}$ & $\mathrm{O}_{4}$ \\
\hline
\end{tabular}

Dalam desain nonequivalent control group design pretest posttest, satu kelompok ditentukan sebagai kelompok eksperimen yang akan diberikan treatment, sedangkan kelompok lainnya yang tidak diberikan treatment ditentukan sebagai kelompok kontrol, kemudian setiap kelompok melakukan pretest agar mengetahui dan mengukur seberapa besar nilai pengetahuan awal siswa. Pretest tersebut dijadikan sebagai pembanding nilai posttest pada kedua kelompok setelah mendapatkan treatment yang berbeda.

\section{Tempat dan Waktu Penelitian}

Penelitian dilaksanakan pada SD Negeri Sindangkarsa 2 Tapos, tepatnya di Kota Depok. Penelitian dilakukan dalam masa lima bulan yang dimulai dari bulan Januari hingga Mei 2017.

\section{Subjek Penelitian}

Populasi mencakup wilayah yang terkena dampak generalisasi dimana terdapat subyek maupun objek dengan karakteristik dan kualitas tertentu yang dipilih untuk dipelajari lebih lanjut (Sugiyono 2015). Dalam penelitian ini dipilih siswa kelas $2 \mathrm{SD}$ Negeri Sindangkarsa 2 Tapos Depok sebagai populasi yang berjumlah 78 siswa. Kelas tersebut terdiri dari kelas 2A dengan jumlah 39 siswa dan 2B dengan jumlah 39 siswa. Sampel yang merupakan penggalan dari populasi (Sugiyono 2015), menggunakan siswa kelas 2B dengan jumlah 39 siswa, dengan rincian siswa laki-laki berjumlah 20, dan siswa perempuan yang berjumlah 19 . Pengambilan sampel dari kelas 2A dan 2B dilakukan dengan mengambil teknik nonprobability sampling dengan bentuk purposive sampling. Dalam artian, nonprobability sampling tidak menyediakan kesempatan yang serupa kepada anggota sampel untuk dipilih, sedangkan purposive sampling berguna dalam memilih sampling dengan alasan yang sudah tentu (Sugiyono 2015). Bersumber pada hasil analisis data nilai siswa dan hasil wawancara guru, peneliti mempertimbangkan bahwa kelas 2B perlu mendapatkan treatment yang mana akan dijadikan sebagai kelompok eksperimen karena nilai rata-rata siswa kelas 2B lebih rendah dibandingkan nilai rata-rata kelas 2A. Sehingga kelas 2B dijadikan sebagai sampel dalam penelitian. 


\section{Variabel Penelitian}

Variabel penelitian perlu untuk ditentukan agar memperoleh informasi lebih lanjut (Sugiyono 2016). Penelitian ini menggunakan variabel bebas yaitu media pembelajaran Geoboard, dan variable terikatnya adalah hasil belajar siswa.

\section{Definisi Konseptual dan Operasional Variabel Penelitian}

Di dalam penelitian ini, diberi batasan pengertian-pengertian untuk memberikan kesepakatan mengenai persepsi mengenai variabel-variabel yang digunakan, diantaranya

\section{Definisi konseptual}

Media pembelajaran Geoboard adalah media dalam pembelajaran terbuat dari kayu tipis yang ditancapkan paku pada bidangnya, kemudian paku-paku tersebut disusun sedemikian rapi dengan jarak yang sama hingga berbentuk menyerupai persegi satuan dan dalam penggunaannya dibutuhkan karet gelang untuk membuat bangun-bangun geometri pada papan.

Hasil belajar dalam penelitian ini sama maknanya dengan hasil optimal yang diperoleh siswa kelas 2 SDN Sindangkarsa 2 setelah siswa mengikuti serangkaian aktivitas dan kegiatan belajar pada mata pelajaran matematika, terutama pada materi unsur-unsur bangun datar sederhana.

\section{Definisi operasional}

Definisi operasional dari hasil belajar yaitu skor yang merupakan akibat dari tes yang berisi tentang pengenalan berbagai macam bangun datar segitiga, segi empat, dan lingkaran beserta unsur-unsur yang membentuknya yaitu sisi, sudut, dan titik sudut.
Adapun definisi operasional dari respon siswa yaitu skor yang merupakan hasil olah dari angket yang berisi tentang tanggapan siswa, ketertarikan siswa, perhatian siswa, peran aktif siswa ketika pembelajaran matematika berlangsung.

\section{Teknik dan Instrumen Pengumpulan Data}

Pengumpulan data merupakan hasil dari perpaduan antara teknik maupun metode selama kegiatan penelitian, dimana instrumennya telah diketahui mutunya melalui uji validitas serta tingkat reliabilitasnya. Keberadaan data akan memudahkan dalam proses analisis dan penarikan kesimpulan.

\section{Tes hasil belajar}

Kelompok kontrol dan eksperimen samasama diberikan tes berupa pretest dan posttest untuk mengumpulkan data. Pretest dilakukan sebelum sampel diberi teratment, sedangkan posttest dilakukan setelah sampel diberi treatment. Masing-masing pretest maupun posttest yang diberikan berasal dari soal yang sama dimana terdiri dari 35 soal pilihan ganda.

\section{Angket (kuesioner)}

Angket diberikan kepada responden berupa pernyataan dan pertanyaan tertulis untuk mengetahui pendapat responden (Rukaesih dan Ucu 2015). Responden yang ditetapkan adalah berupa sampel penelitian. Angket berisi 10 item dan merupakan angket tertutup yang dipakai selama pelaksanaan penelitian. Angket ini bertujuan untuk mengetahui pendapat siswa setelah diberikan treatment.

\section{Lembar observasi pembelajaran}

Kegiatan observasi merupakan kegiatan mengamati subyek dari penelitian untuk mengetahui dan melihat efek tindakan yang 
telah terlaksana. Lembar observasi dalam penelitian ini, meliputi serangkaian kegiatan yang dilaksanakan guru beserta siswa ketika pembelajaran berlangsung. Teknik dan instrumen pengumpulan data pada penelitian ini diuraikan pada Tabel 2.

Tabel 2 Teknik pengumpulan data

\begin{tabular}{|c|c|c|c|}
\hline $\begin{array}{l}\text { Sumber } \\
\text { Data }\end{array}$ & Jenis Data & $\begin{array}{c}\text { Teknik } \\
\text { Pengumpulan Data }\end{array}$ & Keterangan \\
\hline Guru & $\begin{array}{l}\text { Hasil belajar mapel } \\
\text { matematika }\end{array}$ & Observasi kinerja guru & $\begin{array}{l}\text { Dilakukan ketika } \\
\text { pembelajaran }\end{array}$ \\
\hline Siswa & $\begin{array}{l}\text { Hasil belajar mapel } \\
\text { matematika }\end{array}$ & Observasi kinerja siswa & $\begin{array}{l}\text { Dilakukan ketika } \\
\text { pembelajaran }\end{array}$ \\
\hline Siswa & $\begin{array}{l}\text { Hasil belajar mapel } \\
\text { matematika }\end{array}$ & Tes pilihan ganda & $\begin{array}{l}\text { Dilakukan pada akhir } \\
\text { pembelajaran }\end{array}$ \\
\hline Siswa & $\begin{array}{l}\text { Respon siswa terhadap } \\
\text { pembelajaran }\end{array}$ & $\begin{array}{l}\text { Angket respon siswa, } \\
\text { wawancara }\end{array}$ & $\begin{array}{l}\text { Setelah proses } \\
\text { pembelajaran }\end{array}$ \\
\hline
\end{tabular}

\section{Uji Coba Instrumen}

Kevalidan dari instrumen diuji untuk mengetahui mutu instrumen tersebut ketika digunakan waktu pengukuran (Sugiyono 2016). Koefisien korelasi dapat ditafsirkan dengan mengambil kriteria seperti pada Tabel 3.

Tabel 3 Kriteria validitas

\begin{tabular}{cl}
\hline $\begin{array}{c}\text { Koefisien } \\
\text { Korelasi }\end{array}$ & \multicolumn{1}{c}{ Kriteria } \\
\hline $0,800-1,000$ & Validitas sangat tinggi \\
$0,600-0,800$ & Validitas tinggi \\
$0,400-0,600$ & Validitas cukup \\
$0,200-0,400$ & Validitas rendah \\
$0,00-0,200$ & Validitas sangat rendah \\
& (Tidak Valid) \\
\hline
\end{tabular}

Sumber: Arikunto (2012)

Reliabilitas adalah kualitas yang menunjukkan kemantapan (counsistency) ekuivalensi; atau stabilitas dari suatu pengukuran yang dilakukan. Estimasi reliabilitas diterapkan pada instrumen berbentuk tes pilihan ganda dengan penggunaan alternatif pilihan ganda A, B, dan C. Data dinyatakan reliabel ketika nilai reliabilitasnya lebih dari 0,70. Koefisien korelasi reliabilitas instrumen diinterpretasikan pada Tabel 4.
Tabel 4 Kriteria reliabilitas

\begin{tabular}{ll}
\hline \multicolumn{1}{c}{ Koefisien Korelasi } & \multicolumn{1}{c}{ Kriteria } \\
\hline $0,00-0,19$ & Sangat rendah \\
$0,20-0,39$ & Rendah \\
$0,40-0,59$ & Sedang \\
$0,60-0,79$ & Tinggi \\
$0,80-1.00$ & Sangat Tinggi \\
\hline Sumber: Arikunto (2011) &
\end{tabular}

Selain menggunakan uji validitas serta reliabilitas, dilakukan pula pengukuran kualitas butir tiap soal di instrument tes berupa tingkat kesukaran serta daya pembeda.

Daya beda adalah daya pembeda soal yang menyatakan adanya perbedaan kemampuan individu, yaitu membedakan siswa dengan kemampuan tinggi atau pandai dengan siswa dengan kemampuan rendah (Hamzah 2014). Daya beda instrumen diinterpretasikan pada Tabel 5.

Tabel 5 Kriteria daya beda

\begin{tabular}{ll}
\hline \multicolumn{1}{c}{ Interval } & \multicolumn{2}{c}{ Kriteria } \\
\hline $0,00-0,20$ & Jelek \\
$0,21-0,40$ & Cukup \\
$0,41-0,70$ & Baik \\
$0,71-1,00$ & Baik Sekali \\
\hline Sumber: Arikunto (2012) & \\
\multicolumn{2}{c}{ Adapun tingkat kesukaran butir soal } \\
merupakan suatu & indikator untuk
\end{tabular}


mengetahui soal tersebut termasuk dalam kategori susah, sedang, atau mudah (Hamzah 2014). Kriteria indeks kesukaran instrumen disajikan pada Tabel 6.

Tabel 6 Kriteria indeks kesukaran

\begin{aligned} & \hline \multicolumn{1}{c}{ Interval } \multicolumn{1}{c}{ Kriteria } \\ & \hline P $0,00-0,30$ Sukar \\ & P $0,31-0,70$ Sedang \\ & P $0,71-1,00$ Mudah \\ & \hline\end{aligned}

Hasil pengujian instrumen yang didapat selanjutnya memasuki tahap analisis butir soal, untuk mengetahui mutu tiap soal yang akan digunakan dalam pengambilan data. Analisis mencakup validitas butir soal, tingkat kesukaran, daya pembeda, dan reliabilitas soal. Untuk mencari nilai reliabilitas, validitas, daya beda, dan tingkat kesukaran dilakukan pada setiap butir soal, dengen menggunakan program Anates V.4. Berdasarkan analisis soal, beberapa soal telah mencukupi syarat untuk pengambilan data dan ada beberapa yang tidak dapat digunakan.

Berdasarkan data rekapitulasi hasil uji coba instrument pilihan ganda menghasilkan, dari 40 soal yang diujicobakan, 25 soal dapat langsung digunakan, 4 soal tidak digunakan karena tidak sesuai dengan kriteria soal yang baik, 1 soal tidak digunakan karena sudah terwakili oleh butir soal lainnya untuk indikator yang sama, dan 10 soal yaitu soal nomor 5, 6, 13, 15, 21, 26, 27, 32, 34, dan 39 sebelum digunakan mengalami perbaikan belum memenuhi kriteria soal yang baik.

Oleh karena itu, butir soal yang digunakan adalah yang memenuhi syarat kevalidan, sehingga yang digunakan sebanyak 35 soal. Keputusan diambil dengan melihat hasil judgment dosen ahli dan uji coba instrumen. Adapun untuk estimasi reliabilitas instrumen hasil belajar matematika yaitu $r=0,76>0,70$, diketahui bahwa instrumen penelitian dinyatakan reliabel, dan termasuk dalam kategori "tinggi".

\section{Teknik Analisis Data}

Data statistik yang dipakai dalam analisis data penelitian ini adalah statistik deskriptif dan statistik inferensial. Statistik deskriptif yaitu cara pendeskripsian dan pengembangan suatu hasil dari pengumpulan data untuk mendapatkan sebuah kesimpulan yang sesuai dengan tujuan penelitian. Sedangkan, statistik inferensial yaitu penggolongan data angka sehingga dapat menghasilkan suatu informasi yang menghasilkan kesimpulan (Sugiyono 2015). Analisis deskriptif dilihat melalui skor rata-rata dan varians pada kelas eksperimen maupun kontrol. Selajutnya, analisis inferensial dianalisis dengan menghitung $N$-Gain yang diperoleh berdasarkan perhitungan terhadap data akhir hasil belajar siswa dengan rumus Hake.

$$
\mathrm{G}=\frac{s_{\text {posttest }}-s_{\text {pretest }}}{S_{\text {maksimum }}-s_{\text {pretest }}}
$$

Hasil perhitungan gain yang didapatkan selanjutnya diinterpretasikan berdasarkan Tabel 7.

Tabel 7 Tabel kriteria N-Gain

\begin{tabular}{ll}
\hline \multicolumn{1}{c}{ N-Gain } & \multicolumn{1}{c}{ Kriteria } \\
\hline $\mathrm{G} \geq 0,7$ & Tinggi \\
$0,3 \leq \mathrm{G}<0,7$ & Sedang \\
$\mathrm{G}<0,3$ & Rendah \\
\hline
\end{tabular}

Untuk membuktikan signifikansi perbedaan kelas kontrol dan eksperimen, dilakukan pengujian statistik One Sample TTest dan dilajutkan Independent Sample TTest melalui SPSS 21. Sebelum dilakukan uji 
statistik tersebut, dilakukan uji prasyarat normalitas dan homogenitas varians.

\section{Prosedur Penelitian}

Prosedur penelitian ini dilakukan dengan tiga tahap, yaitu tahap persiapan, tahap pelaksanaan, dan penyusunan laporan sebagai berikut: 1) persiapan, pada tahap pertama peneliti mengajar di kelas 2B (kelompok eksperimen) dan 2A (kelompok kontrol) dengan mempersiapkan kebutuhan yang digunakan pada kegiatan pembelajaran yaitu membuat RPP dengan menggunakan pendekatan saintifik serta menyiapkan media pembelajaran geoboard untuk kelas 2B dan media pembelajaran Tangram 44 untuk kelas 2A; 2) pelaksanaan, pada tahap kedua ini guru terlebih dahulu memberikan pretest sebelum memulai pembelajaran kepada kelompok eksperimen serta pada kelompok kontrol yaitu sebanyak 35 soal pilihan ganda. Kemudian, guru melaksanakan kegiatan pembelajaran dengan menggunakan pendekatan saintifik dengan menerapkan media pembelajaran geoboard pada kelompok eksperimen, sedangkan pada kelas kontrol diterapkan media pembelajaran Tangram 44; 3) setelah proses pembelajaran berakhir, kemudian guru memberikan posttest sebanyak 35 soal pilihan ganda yang telah diuji validitas dan reliabilitasnya di kelas 3 SDN Sindangkarsa 2 Depok. Setelah memberikan posttest, peneliti menyebarkan angket kepada siswa kelas eksperimen yaitu kelas 2B. Angket tersebut untuk mengetahui respon siswa terhadap media pembelajaran geoboard. Penyebaran angket berlangsung tanpa hambatan dan berjalan lancar. Angket disebarkan kepada 39 siswa yang ditetapkan sebagai sampel penelitian.

Penyusunan laporan, tahap akhir yaitu data hasil pretest dan posttest yang telah terkumpul kemudian dianalisis ke dalam uji prasyarat (uji normalitas dan homogenitas) untuk mengetahui data berdistribusi normal dan homogen. Kemudian dilanjut kepada uji hipotesis untuk menguji keefektifan media pembelajaran geoboard dengan menggunakan one sample t-test.

\section{HASIL DAN PEMBAHASAN}

\section{Hasil}

Data hasil pembelajaran kemudian dikumpulkan dan disusun kedalam sebuah tabel yang mana data berasal dari pretest, posttest, peningkatan prestasi (gain) kelompok eksperimen dan kelompok kontrol. Kemudian, data dianalisis untuk mengetahui rerata, varians, skor maksimal dan minimum, yang tersaji pada Tabel 8 dan divisualisasikan ke dalam bentuk diagram seperti Gambar 2.

Tabel 8 Analisis deskriptif hasil belajar siswa

\begin{tabular}{lrrrrrr}
\hline \multirow{2}{*}{ Nilai } & \multicolumn{2}{c}{ Pretest } & \multicolumn{2}{c}{ Posttest } & \multicolumn{2}{c}{$k$} \\
\cline { 2 - 7 } & \multicolumn{1}{c}{ Eksp. } & \multicolumn{1}{c}{ Kontrol } & \multicolumn{1}{c}{ Eksp. } & Kontrol & \multicolumn{1}{c}{ Eksp. } & \multicolumn{1}{c}{ Kontrol } \\
\hline Rata-Rata & 53,77 & 54,87 & 70,43 & 64,58 & 16,65 & 9,71 \\
Varians & 106,46 & 125,29 & 136,79 & 162,27 & 74,97 & 195,72 \\
Skor maksimum ideal & 100 & 100 & 100 & 100 & 100 & 100 \\
Skor minimum ideal & 0 & 0 & 0 & 0 & 0 & 0 \\
Skor maksimum & 74,3 & 74,3 & 88,6 & 85,7 & 28,6 & 31,4 \\
Skor minimum & 37,1 & 37,1 & 37,1 & 37,1 & -2.9 & $-31,5$ \\
\hline
\end{tabular}


Berdasarkan Tabel 8, hasil belajar (posttest) kelompok eksperimen setelah mendapatkan treatment (media Geoboard)sangat baik dibanding dengan hasil belajar dikelompok kontrol dengan penggunaan media Tangram 44. Demikian pula N-Gain kelas eksperimen memperoleh nilai lebih besar dibanding kontrol.

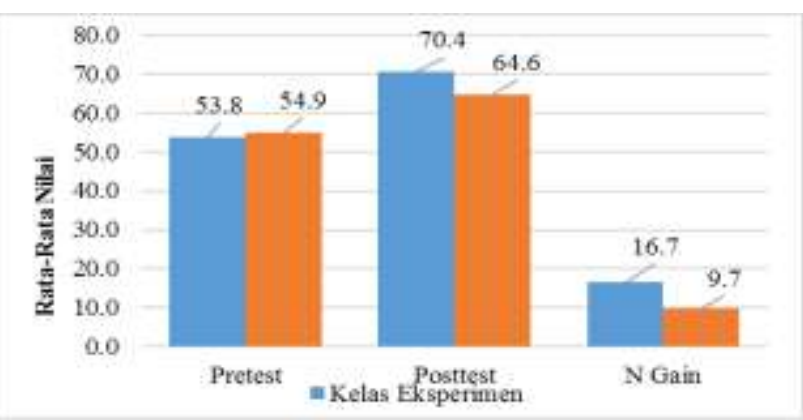

Gambar 2 Peningkatan hasil belajar kelompok eksperimen dan kontrol

Pada Gambar 2 dijelaskan bahwa kelompok eksperimen yaitu kelompok yang diberikan treatment dengan media Geoboard mengalami peningkatan terhadap prestasi belajar dimana besarnya rata-rata gain 16,7. Sedangkan prestasi belajar kelompok kontrol dengan bantuan media pembelajaran Tangram 44 lebih kecil dengan besar rata-rata gain 9,7. Meskipun rerata gain kedua kelas memiliki kategori "sedang", namun rerata nilai gain kelompok eksperimen lebih tinggi dibanding kelompok kontrol. Peningkatan dengan kategori sedang karena selama pembelajaran masih terbatas yaitu hanya dilakukan 4 kali pertemuan, sedangkan perubahan yang besar terlihat jelas bila proses belajar selalu continue.

\section{Uji Prasyarat Analisis Data}

Uji prasyarat analisis data dilakukan melalui uji normalitas serta homogenitas. Uji normalitas dilakukan agar mengetahui tingkat distribusi normal populasi penelitian. Pengujian dilakukan menggunakan rumus Kolmogorov-Smirnov Test pada program SPSS 21. Hipotesis yang digunakan yaitu:

$\mathrm{H}_{0}$ : data populasi terdistribusi normal

$\mathrm{H}_{1}$ : data populasi tidak terdistribusi normal

Dengan kriteria keputusan: $\mathrm{H}_{0}$ diterima jika p-value (sig) $>$ a, dengan $a=0,05$. Tabel 9 dan Tabel 10 menunjukkan uraian uji normalitas pretest dan posttest.

Tabel 9 Uji normalitas pretest

\begin{tabular}{lcc}
\hline \multirow{2}{*}{ Kelompok } & \multicolumn{2}{c}{ Kolmogorov-Smirnov } \\
\cline { 2 - 3 } & $\mathrm{df}$ & \multicolumn{1}{c}{ Sig. } \\
\hline Eksperimen & 39 & 0,160 \\
\hline Kontrol & 39 & $\mathbf{0 , 2 0 0}$ \\
\hline
\end{tabular}

Tabel 10 Uji normalitas posttest

\begin{tabular}{lcc}
\hline \multirow{2}{*}{ Kelompok } & \multicolumn{2}{c}{ Kolmogorov-Smirnov } \\
\cline { 2 - 3 } & $\mathrm{df}$ & \multicolumn{1}{c}{ Sig. } \\
\hline Eksperimen & 39 & 0,143 \\
\hline Kontrol & 39 & 0,130 \\
\hline
\end{tabular}

Dilakukan uji homogenitas agar dapat membuktikan apakah data hasil selama penelitian berupa hasil belajar (pretest dan posttest) pada kelompok eksperimen serta kontrol mempunyai nilai varians yang homogen atau tidak. Statistik uji homogenitas ini menggunakan Uji F (Fisher) dua variabel dengan penjabaran rumus yaitu:

$$
\mathrm{F}=\frac{\text { Varians terbesar }}{\text { Varians terkecil. }}
$$

Hipotesis yang dipakai yaitu:

$\mathrm{H}_{0}: s_{1}^{2}=s_{2}^{2}$ (varians data homogen) $\mathrm{H}_{1}: s_{1}^{2} \neq s_{2}^{2}$ (varians data tidak homogen)

Kriteria keputusan dikatakan homogen apabila memenuhi ketentuan $F_{\text {hitung }}<\mathrm{F}_{\text {tabel }}$ dan data dikategorikan homogen. Uji homogenitas ditunjukkan pada Tabel 11 . 
Tabel 11 Uji homogenitas

\begin{tabular}{lrrrr}
\hline \multirow{2}{*}{ Statistik } & \multicolumn{2}{c}{ Pretest } & \multicolumn{2}{c}{ Posttest } \\
\cline { 2 - 5 } & Eksp & Kontrol & Eksp & Kontrol \\
\hline$S S^{2}$ & 10,1 & 11,0 & 11,5 & 12,5 \\
Fhitung & 102,7 & 121,1 & 132,3 & 157,1 \\
Ftabel & \multicolumn{2}{c}{1,18} & \multicolumn{2}{c}{1,19} \\
& \multicolumn{2}{c}{4,11} & 4,11 \\
Keterangan & Homogen & \multicolumn{2}{c}{ Homogen } \\
\hline
\end{tabular}

\section{Uji Hipotesis}

Pengujian hipotesis dilakukan untuk melihat pengaruh penggunaan media Geoboard pada pelajaran matematika. Pengujian dilakukan terhadap nilai rata-rata posttest kelompok eksperimen serta kontrol yang dianalisis melalui statistik One Sample T-Test menggunakan program SPSS 21, dengan kriteria keputusannya adalah $\mathrm{H}_{0}$ ditolak jika nilai signifikasi lebih kecil dari 0,05 , maka bentuk hipotesisnya sebagai berikut:

$\mathrm{H}_{0}: \mu_{\mathrm{p}}<75(\mathrm{KKM})$

$\mathrm{H}_{1}: \mu_{\mathrm{p}} \geq 75$ (KKM)

Ket : $\mu_{\mathrm{p}}$ : rata-rata hasil belajar

Independent Sample T-Test dilakukan untuk melihat perbedaan hasil belajar antara penggunaan media geoboard dan media Tangram 44. Uji hipotesis untuk nilai posttest dalam uji penelitian ini ialah ujihipotesis pihak kanan, sebagai berikut:

$\mathrm{H}_{0}: \mu_{e} \leq \mu_{k} \quad$ (Kelompok kontrol memberikan pengaruh yang baik dan positif dibandingkan kelas kontrol)

$\mathrm{H}_{1}: \mu_{e}>\mu_{k} \quad$ (Kelompok eksperimen memberikan pengaruh yang baik dan positif dibandingkan kelas kontrol)

Kriteria keputusannya, $\mathrm{H}_{0}$ ditolak jika nilai $\mathrm{T}_{\text {hitung }}>\mathrm{T}_{\text {tabel }}$ dimana kelompok eksperimen dinyatakan memberikan pengaruh yang baik dan positif dibandingkan kelompok eksperimen.

\section{Respon Siswa}

Angket disebarkan ke setiap siswa agar mampu mengukur minat dan respon belajar saat pembelajaran. Gambar 3 menyajikan hasil data angket untuk setiap respon siswa terhadap media geoboard.

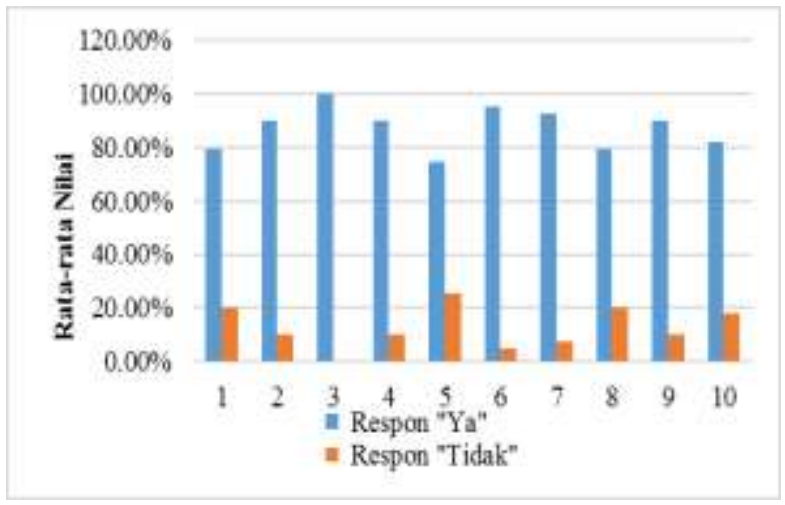

Gambar 3 Hasil respon siswa terhadap media geoboard

Interpretasi dari Gambar 3 menunjukkan respon positif dari 39 siswa dengan menggunakan media geoboard dimana sebanyak 31 siswa merasa materi tentang bangun datar dan unsurnya jadi lebih mudah untuk dipelajari, 35 siswa menjadi suka dengan pelajaran matematika, 39 siswa menyatakan termotivasi lebih giat saat belajar, 35 siswa menyatakan lebih bersemangat, 29 siswa menyatakan antusisme dan ingin tahu yang meningkat, 37 siswa menyatakan lebih cepat paham, 36 siswa menyatakan belajar menjadi lebih bersungguh-sungguh, 31 siswa menyatakan mampu menjawab berbagai pertanyaan guru, 35 siswa menyatakan dapat menambah pengetahuan, 32 siswa dapat berbagi pengetahuan dengan teman. Dapat ditarik simpulan dimana respon positif setiap siswa meningkat ketimbang respon negatif. Siswa merasa bersungguh-sunguh, termotivasi, berbagi pengetahuan, serta giat belajar sehingga tercipta sebuah pembelajaran efektif. 


\section{Observasi Pembelajaran}

Data tentang keterlaksanaan pembelajaran diambil dengan menggunakan teknik observasi melalui pengamatan aktivitas siswa beserta guru saat proses belajar berlangsung. Kegiatan yang dilakukan pada tahapan ini yaitu menyiapkan silabus, RPP (Rencana Pelaksanaan Pembelajaran), menyiapkan materi sesuai capaian KD (kompetensi dasar) dan mempersiapkan media pembelajaran.

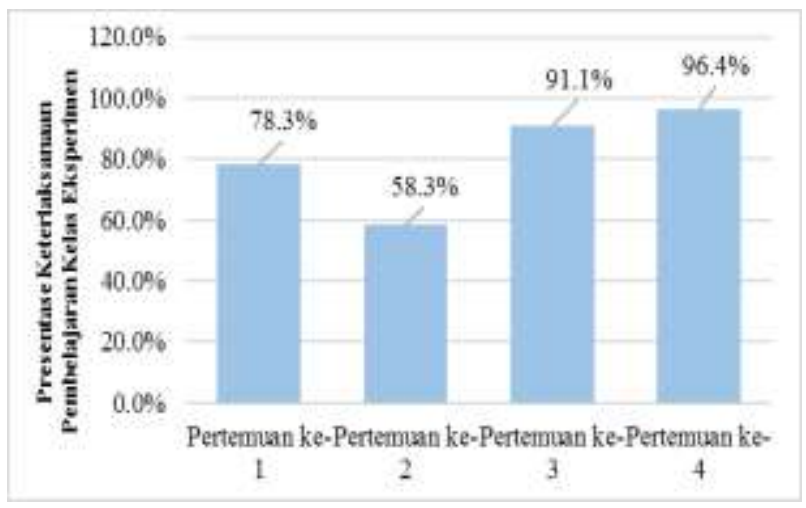

Gambar 4 Persentase keterlaksanaan pembelajaran kelompok eksperimen

Persentase aktivitas guru dipertemuan pertama mencapai $78,3 \%$ dengan kategori "efektif", pertemuan kedua sebesar 58,3\% dengan kategori "cukup efektif", pertemuan ketiga mencapai 91,1\% dengan kategori "sangat efektif", pertemuan keempat mencapai 96,4\% dengan kategori "sangat efektif".

Berdasarkan Gambar 5 persentase aktivitas guru pada pertemuan pertama kelas kontrol mencapai 78,3\% dengan kategori "efektif", pertemuan kedua sebesar $56,7 \%$ dengan kategori "cukup efektif", pertemuan ketiga mencapai $87,5 \%$ dengan kategori "sangat efektif, pertemuan keempat mencapai 94,6\% yang termasuk kategori "sangat efektif". Simpulannya, pembelajaran berlangsung baik di kedua kelas (eksperimen maupun kontrol).

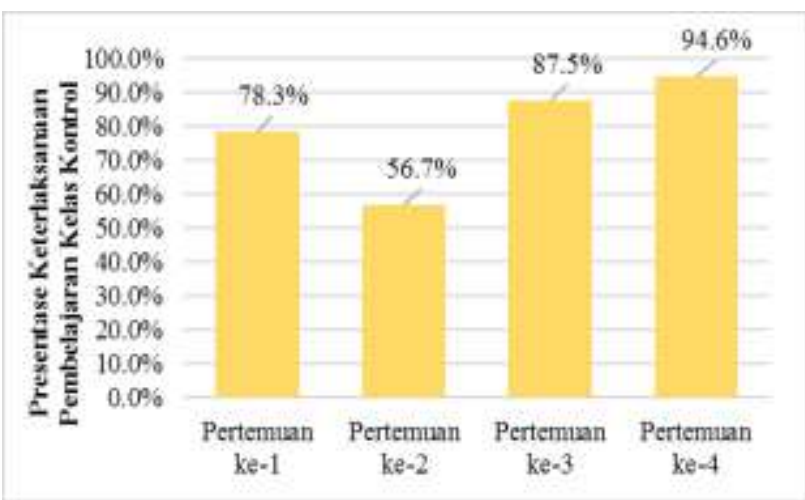

Gambar 5 Persentase keterlaksanaan pembelajaran kelompok kontrol

Adapun observasi siswa, kelas eksperimen maupun kontrol dilakukan kepada 5 siswa yang kategori masingmasing memiliki kriteria nilai biasa saja, tidak tinggi tidak pula rendah. Tahapantahapan pada pembelajaran terlaksana baik dan siswa terlibat aktif dalam pembelajaran. Siswa memperhatikan penjelasan materi, melakukan unjuk kerja sesuai petunjuk LKS, merespon hasil unjuk kerja kelompok lain, dan mengerjakan tugas PR.

\section{Pembahasan}

Rendahnya nilai belajar matematika serta tidak adanya media pembelajaran buatan guru saat belajar menjadi masalah utama dalam penelitian ini. Metode atau model pembelajaran yang dipilih guru juga kurang bervariasi sehingga pembelajaran terkesan monoton. Salah satu bentuk solusi yang ditawarkan peneliti dengan harapan terdapat peningkatan motivasi dan hasil belajar melalui penggunaan media konkret.

Penggunaan benda konkret kepada masing-masing kelompok eksperimen serta kontrol, diperkuat dengan pendapat ahli yang menyatakan bila suatu benda yang abstrak lalu dikonkretkan maka lebih mudah dan sederhana diterima oleh akal pikiran (Azhar 2015). Hasil analisis mengenai pelaksanaan pembelajaranpada data pretest, posttest, dan gain kelompok 
eksperimen dan kontrol kemudian diuji normalitas, homogenitas, dan hipotesisnya.

Hasil penelitian selanjutnya, data pretestposttest dianalisis normalitasnya dengan menggunakan

Kolmogorov-Smirnov. Diketahui data pretest kelompok eksperimen sig $=0,160>0,05$, dan data pretest kelompok kontrol diketahui sig $=$ $0,200>0,05$ dengan taraf signifikansi 5\%dimana $\mathrm{H}_{0}$ diterima dengan populasi berdistribusi normal. Sedangkan, hasil analisis dari data posttest kelompok eksperimen diketahui sig $=0,143>0,05$, dan data posttest kelompok kontrol diketahui sig $=0,130>0,05$ dengan taraf signifikansi $5 \%$ dimana $\mathrm{H}_{0}$ diterima berarti populasi berdistribusi normal.

Selanjutnya dilakukan uji homogenitas dengan uji $F$ (Fisher) varians. Diperoleh hasil data skor pretest kelompok eksperimen serta kontrol dengan $\mathrm{F}_{\text {hitung }}=$ 1,18; $F_{\text {tabel }}=4,11$ kriteria 5\%. Didapat $\mathrm{F}_{\text {hitung }}<\mathrm{F}_{\text {tabel, }}$ maka data pretest kelompok eksperimen serta kontrol memiliki varians homogen. Adapun skor posttest kelompok eksperimen serta kontrol dengan $F_{\text {hitung }}=$ 1,$19 ; \mathrm{F}_{\text {tabel }}=4,11$ kriteria 5\%. Didapat $\mathrm{F}_{\text {hitung }}<\mathrm{F}_{\text {tabel, }}$ maka data posttest kelompok eksperimen serta kontrol memiliki varianshomogen.

Uji hipotesis menggunakan One Sample TTest. Dari hasil analisis pengujian hipotesis One Sample T-Test melalui program SPSS, kedua kelompok eksperimen serta kontrol sama-sama memperoleh hasil sig $=0,000<$ 0,05 , berarti hipotesa $\mathrm{H}_{0}$ ditolak, yang artinya sama-sama terdapat pengaruh positif dalam penggunaan media geoboard ataupun media pembelajaran Tangram 44 .

Oleh karena hasil uji hipotesis menggunakan One Sample T-Test samasama terdapat pengaruh dalam menerapkan suatu media yang konkret pada masingmasing kelompok, maka peneliti melakukan uji lanjut dengan program SPSS 21 menggunakan Independent Sample T-Test. Tujuan pengujian ini agar mengetahui pengaruh positif dari kelompok eksperimen. Hasil dari analisis data pengujian Independent Sample T-Test terlihatnilai $\mathrm{T}_{\text {hitung }}=2,111$, dan $\mathrm{T}_{\text {tabel }}=1,687$ dengan kriteria $\mathrm{T}_{\text {hitung }}>\mathrm{T}_{\text {tabel }}$ maka $\mathrm{H}_{0}$ ditolak, berarti kelompok eksperimen memberikan pengaruh positif dan lebih baik dibandingkan kelompok kontrol.

Peningkatan tersebut diperkuat dengan pendapat para ahli. Sundayana menyatakan media pembelajaran geoboard membantu guru mengkonstruksi atau menanamkan konsep geometri dalam mempelajari bangun datar. Tutak (20150 juga menyatakan dalam penelitiannya penggunaan dari benda yang bersifat manipulatif seperti geoboard sangat menekankan suatu instruksi geometri yang efektif. Kemudian adanya penelitian yang relevan dan mendukung penelitian ini, bahwa penerapan media pembelajaran geoboard memberikan hasil lebih baik untuk siswa Kelas III SDN 1 Peresak.

Selain itu, respon siswa pada penggunaan media geoboard hampir seluruhnya menunjukkan respon positif, siswa sangat bersemangat dan termotivasi serta lebih giat saat belajar. Hal ini terbukti dari hasil angket respon siswa untuk mengetahui indikator motivasi belajar sebanyak 100\% siswa menyatakan lebih giat dan termotivasi untuk belajar dan 89,7\% siswa menyatakan bersemangat mempelajari bangun-bangun datar. Sebanyak 79\% siswa menyatakan materi bangun datar jadi mudah dipahami dan 94,9\% siswa menyatakan materi bangun datar lebih cepat dipahami.

Adapun indikator rasa ingin tahu dan kesungguhan dalam belajar sebanyak 74,4\% siswa menyatakan rasa ingin tahu 
bertambah ketika belajar dan 92,3\% siswa menyatakan kesungguhan dalam pembelajaran menjadi meningkat. Kemudian, sebanyak $89,7 \%$ siswa menyatakan menjadi suka dengan pelajaran matematika dan $79,5 \%$ siswa mampu menjawab berbagai pertanyaan guru. Sebanyak $89,7 \%$ pengetahuan siswa menjadi bertambah dan $82,1 \%$ siswa dapat berbagi pengetahuan terhadap temantemannya.

\section{KESIMPULAN DAN IMPLIKASI}

\section{Kesimpulan}

Mengetahui pengaruh penggunaan media geoboard terhadap hasil belajar merupakan tujuan utama penelitian ini. Berdasarkan analisis data dan pembahasan, dapat dibuat kesimpulan bahwa terdapat pengaruh positif yang signifikan melalui hasil analisis data independent t-test dengan taraf signifikansi $5 \%$ diperoleh nilai $\mathrm{T}_{\text {hitung }}=$ 2,111 , dan $\mathrm{T}_{\text {tabel }}=1,687$, hal ini menyatakan bahwa kelompok eksperimenmemberikan pengaruh positif lebih baik daripada kelompok kontrol. Dapat disimpulkan, penggunaan media geoboard efektif ketika digunakan saat pembelajaran geometri materi bangun datar. Kemudian, hasil analisis dari data angket menunjukkan respon positif terhadap media geoboard. Siswa menjadi lebih mudah paham dalam memahami dan mengkonstruksi konsep geometri dan menjadi lebih termotivasi ketika melaksanakan pembelajaran.

\section{Implikasi}

Media pembelajaran geoboard menjadi salah satu alternatif dari pemecahan masalah matematika terkait materi geometri. Pembuatan dari media geoboard ini dianggap mudah dan dapat digunakan ulang hingga berkali-kali sehingga menjadi keunggulan dari media ini sehingga bersifat ekonomis dalam pemakaiannya. Namun, sebaiknya pembuatan media geoboard ini dilakukan jauh sebelum pembelajaran dilaksanakan karena pembuatannya memerlukan banyak waktu.

\section{DAFTAR PUSTAKA}

Arikunto S. 2011. Dasar-dasar evaluasi pendidikan. Edisi revisi. Rineka Cipta, Jakarta.

Arikunto S. 2012. Dasar-dasar evaluasi pendidikan. Edisi 2. Bumi Aksara, Jakarta.

Hamzah A dan Muhlisrarini. 2014. Perencanaan dan strategi pembelajaran matematika. Raja Grafindo Persada, Jakarta.

Heinich R, M Molenda, JD Russell, dan SE Smaldino. 2002. Instructional media and technology for learning. $7^{\text {th }}$ edition. Prentice Hall, Inc., New Jersey.

Indriyastuti. 2012. Matematika untuk kelas 2 SD dan MI. Tiga Serangkai Pustaka Mandiri, Solo.

Lestari S, D Amaliah, A Intermediana, dan N Amega. 2015. Strategi belajar dan pembelajaran. Unindra Press, Jakarta.

Maolani RA dan U Cahyana. 2015. Metodologi penelitian pendidikan. Raja Grafindo Persada, Jakarta.

Mulyaningsih C. 2014. Peningkatan pemahaman konsep bangun datar melalui pendekatan matematika realistik pada siswa kelas IV SDN Sokokulon 2 Margorejo Pati. Skripsi. Universitas Surakarta, Surakarta.

Purwanto. 2014. Evaluasi hasil belajar. Pustaka Pelajar, Yogyakarta.

Santoso J. 2014. Upaya meningkatkan hasil belajar matematika dengan menggunakan alat peraga papan berpaku pada kelas III SDN 6 Panarung 
Palangkaraya tahun pelajaran 2013/2014. Skripsi. Universitas Muhammadiyah Palangka Raya, Riau.

Sugiyono. 2015. Statistika untuk penelitian. Alfabeta, Bandung.

Sugiyono. 2016. Metode penelitian pendidikan pendekatan kuantitatif, kualitatif, dan r\&d. Alfabeta, Bandung.
Sundayana R. 2016. Media dan alat peraga dalam pembelajaran matematika. Alfabeta, Bandung.

Tutak FA. 2015. A study of geometry content knowledge of elementary preservice teachers. International Electronic Journal of Elementary Education.

Usman MU. 2011. Menjadi guru profesional. Remaja Rosdakarya, Bandung. 